Article

\title{
Scale up of Microbial Fuel Cell Stack System for Residential Wastewater Treatment in Continuous Mode Operation
}

\author{
Rodrigo Valladares Linares ${ }^{1}{ }^{\circledR}$, Jorge Domínguez-Maldonado ${ }^{2}$, Ernesto Rodríguez-Leal ${ }^{1}$, \\ Gabriel Patrón ${ }^{1}$, Alfonso Castillo-Hernández ${ }^{1}$, Alfredo Miranda ${ }^{1}$, Diana Diaz Romero ${ }^{1}$, \\ Rodrigo Moreno-Cervera ${ }^{2}$, Gerardo Camara-chale ${ }^{2}$, Carlos G. Borroto ${ }^{2}$ \\ and Liliana Alzate-Gaviria ${ }^{2, *}$ \\ 1 Innovation, Research and Development Rotoplas, Pedregal 24 Floor 19, Miguel Hidalgo, Mexico City 11040, \\ Mexico; rvalladares@rotoplas.com (R.V.L.); erodriguezl@rotoplas.com (E.R.-L.); gpatron@rotoplas.com (G.P.); \\ acastillo@rotoplas.com (A.C.-H.); amirandag@rotoplas.com (A.M.); d.diazr@areakvo.com (D.D.R.) \\ 2 Renewable Energy Unit, Yucatan Center for Scientific Research A.C (CICY), Carretera Sierra \\ Papacal-Chuburná Puerto, Km 5, Sierra Papacal, Mérida CP 97302, Mexico; joe2@cicy.mx (J.D.-M.); \\ Rodrigo.moreno@cicy.mx (R.M.-C.); gerardo.camara@cicy.mx (G.C.-c.); carlos.borroto@cicy.mx (C.G.B.) \\ * Correspondence: lag@cicy.mx; Tel.: +52-999-930-0760
}

Received: 2 October 2018; Accepted: 24 December 2018; Published: 28 January 2019

check for updates

\begin{abstract}
The most important operational expense during wastewater treatment is electricity for pumping and aeration. Therefore, this work evaluated operational parameters and contaminant removal efficiency of a microbial fuel cell stack system (MFCSS) that uses no electricity. This system consists of (i) septic tank primary treatment, (ii) chamber for secondary treatment containing 18 MFCs, coupled to an energy-harvesting circuit (EHC) that stores the electrons produced by anaerobic respiration, and (iii) gravity-driven disinfection (sodium hypochlorite 5\%). The MFCSS operated during 60 days (after stabilization period) and it was gravity-fed with real domestic wastewater from a house (5 inhabitants). The flow rate was $600 \pm 100 \mathrm{~L} \cdot \mathrm{d}^{-1}$. The chemical oxygen demand, biological oxygen demand, total nitrogen and total phosphorous were measured in effluent, with values of $100 \pm 10 ; 12 \pm 2 ; 9.6 \pm 0.5$ and $4 \pm 0.2 \mathrm{mg} \cdot \mathrm{L}^{-1}$, and removal values of $86 \%, 87 \%, 84 \%$ and $64 \%$, respectively. Likewise, an EHC (ultra-low energy consumption) was built with $6.3 \mathrm{~V} \mathrm{UCC}{ }^{\circledR}$ $4700 \mu \mathrm{F}$ capacitors that harvested and stored energy from MFCs in parallel. Energy management was programmed on a microcontroller Atmega $328 \mathrm{~PB}^{\circledR}$. The water quality of the treated effluent complied with the maximum levels set by the Mexican Official Standard NOM-001-SEMARNAT-1996-C. A cost analysis showed that MFCSS could be competitive as a sustainable and energy-efficient technology for real domestic wastewater treatment.
\end{abstract}

Keywords: microbial fuel cell scale up; decentralized wastewater treatment; residential wastewater treatment system; anaerobic oxidation

\section{Introduction}

Water is fundamental for the development of human life. Prior to the industrial revolution, water was considered an inexhaustible resource, but its constant exploitation has caused scarcity and unavailability throughout some of the most densely populated areas in the world. Urban areas in Mexico used 12.5 billion $\mathrm{m}^{3}$ in 2015 for public supply, returning as wastewater 7.2 billion $\mathrm{m}^{3}$, which was about $58 \%$ of the total water supplied [1]. This indicates that more fresh water could be saved if wastewater in urban areas could be effectively treated and reused. Mexico treated only about $60 \%$ of its wastewater [1]. Water is nowadays a central pole for economic and environmental policies, as well as a 
fundamental topic in managing social strategies. Rivers, ground water, lakes and other sources of fresh water must be taken care of (i.e., avoid illegal wastewater discharges) to prevent a lack of availability and to protect the ecosystem. Microbial fuel cells (MFC) are an emerging technology that can be used to treat wastewater because they function as bioreactors where bacteria become electrocatalysts that convert residual biomass found in wastewater into bioenergy [2].

The first concept where microbes were used to generate electricity was conceived by Potter in 1911. Several developments and applications have been studied since the 1930s with Cohen, Karube in the 1960s, and in the 1980s and 1990s with Benetto, who focused on synthetic mediators, which are still used nowadays [3-6]. It is important to recognize that significant progress has been achieved in several topics relevant to MFCs: (i) efficient bioelectrocatalytic interfaces, (ii) novel low-cost electrodes, (iii) electron transfer mechanism theories, and (iv) understanding bacterial growth and life cycle in the anode. Nevertheless, there is still a knowledge gap to fill before we can achieve the industrialization of MFCs both for power generation and wastewater treatment [7].

Few studies have been published on pilot-scale tests, particularly adapted to practical conditions. The first pilot trial was the "gastrobot", applied in the electronic and robotic field [8]. Recent publications have shown advances in electrode and reactor materials, diverse and novel cell configurations, overall performance in terms of nutrients and contaminants removal and cost analysis; these experiments have been performed in setups that range from 1 to hundreds of liters treated in one batch, with a few attempts at pilot-scale continuous flow based MFC systems [9-14].

MFCs offer unique advantages over traditional wastewater treatment processes, such as low carbon footprint, electricity generation, reduced sludge production, and simple operation and tend to use carbonaceous materials that are cheaper $[15,16]$. MFCs are a promising technology that can change the way we treat wastewater, especially in developing nations where improvements in traditional wastewater technologies give room to significant savings in operation, particularly if MFCs are used to transform the treatment plant into a "net energy producer". The principle behind this concept is the use of exoelectrogenic bacteria to transform the energy inherently found in wastewater into electrical energy, and at the same time remove the nutrients and contaminants in the water $[9,17]$. The microorganisms that are capable of exocellular electron transfer are defined here as exoelectrogenic, although they have been described using various other terms, such as electrochemically active bacteria, anode respiring bacteria and electricigens [17]. The most common terminal electron acceptor for MFCs is oxygen, due to its high redox potential and natural availability. A stack system connected at a circuit is the only way to achieve useful power levels, because individual cells produce a very small amount of net power. This functional implementation implies the use of an optimized circuitry, all aimed to take advantage of the irregular energy production regime in which MFCs work.

To the authors knowledge, the first large scale system installed was set up in a brewery in Yatala, Queensland, Australia. Other studies have been piloted outside of the laboratory environment, such as benthic MFCs, combinations of MFCs and constructed wetlands, floating MFCs in water bodies, hydrogen production enhanced by electrolysis cells, urinal systems, among others [8].

The objective of this trial was to assess the feasibility of a scale up of microbial fuel cell stack system (MFCSS) to be used as a wastewater treatment solution that uses no electricity, becoming a self-sustaining system and complying with Mexican Official Standard NOM-001-SEMARNAT-1996-C for discharges into soil and water [18].

\section{Materials and Methods}

\subsection{AQUOX ${ }^{\circledR}$-Microbial Fuel Cell Stack System (MFCSS)}

A scale up of a MFCSS was designed and installed in a residential unit located in Tixcacal, Yucatan, Mexico. This property is inhabited by 4 persons, with a layout of 3 rooms, 2 bathrooms, a living room, a dining area, kitchen and an uncovered garage area. The MFCSS consists of a septic tank for primary treatment followed by the AQUOX ${ }^{\circledR}$ (18 MFCs for secondary treatment) and finally a disinfection 
system. The start-up ended when steady-state value was reached; this was the average of three consecutive measurements for effluent chemical oxygen demand (COD) when the deviations between the observed values were less than 5\% [8]; as well as obtaining values close to $0.4 \mathrm{~V}$ and $1 \mathrm{~mA}$ in each one of the microbial fuel cells inside the chamber for secondary treatment [2]. Figure 1 shows the layout of the installation. The wastewater inlet to the system flows by gravity and thus no electricity was required to pump the influent. For more details, see Supplementary Materials.

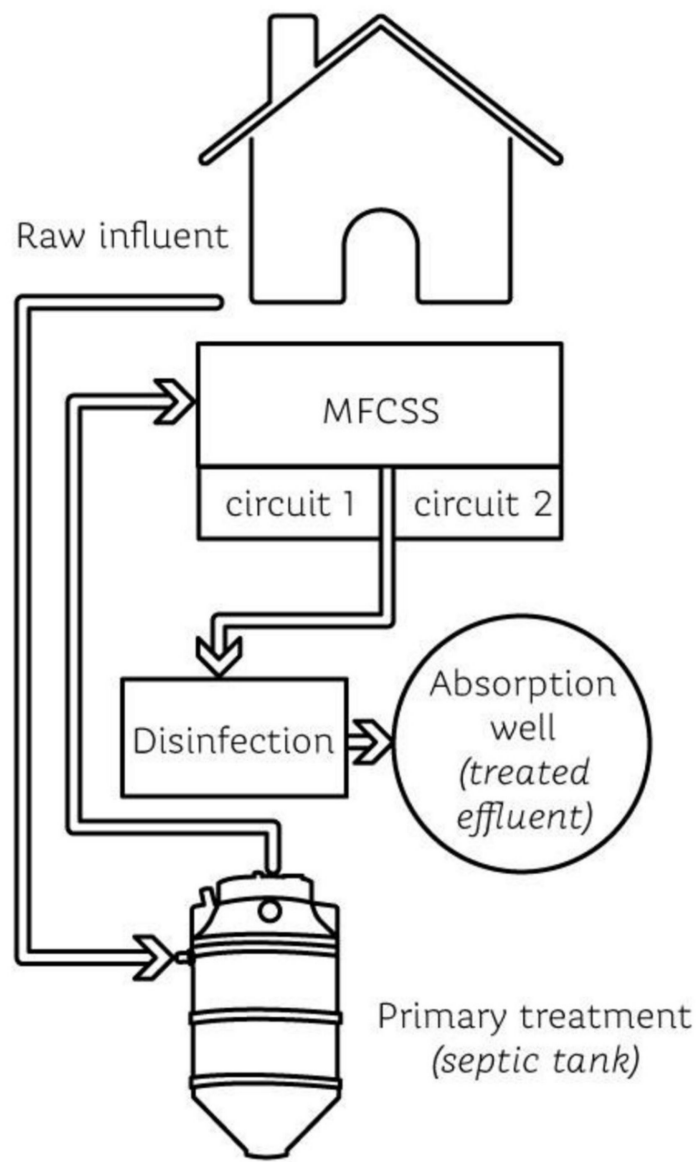

Figure 1. The microbial fuel cell stack system (MFCSS) setup for a real domestic wastewater.

The septic tank for primary treatment had a volume of $1300 \mathrm{~L}$ (constructed in high density polyethylene) and AQUOX ${ }^{\circledR}$ consisted of a concrete chamber with a volume of $700 \mathrm{~L}(100 \mathrm{~cm} \times 90 \mathrm{~cm}$ $\times 78 \mathrm{~cm}$ ) containing 18 MFCs, organized in two groups of 9 (2 stacks). Each stack was coupled to a circuit that harvested the electrons during the anaerobic oxidation of dissolved organic matter in the domestic wastewater. The disinfection system consisted of a chamber for the dissolution of sodium hypochlorite $(5 \%)$ where the fecal coliforms were removed.

Each designed MFC structure was composed by a set of pieces fabricated in acrylonitrile butadiene styrene (ABS) that included the membrane support and polyvinylchloride (PVC) pieces that conform the anode and cathode chamber making a single structure as shown in Figure 2 [2]. The size of each MFC was $10 \mathrm{~cm}$ of diameter and $55 \mathrm{~cm}$ height. Likewise, the cathode used was an air cathode chamber with a membrane-electrode assembly, using Nafion ${ }^{\circledR} 117$ membrane and carbon cloth without catalyst [19]. Stainless steel was used to connect the circuit and coated with heat shrink tubing. Likewise, each MFC had an internal resistance of $350 \pm 60 \Omega$. The domestic wastewater was in contact with the anode (granular activated carbon (GAC) inside a stainless steel mesh) of the MFC which is fully submerged. 


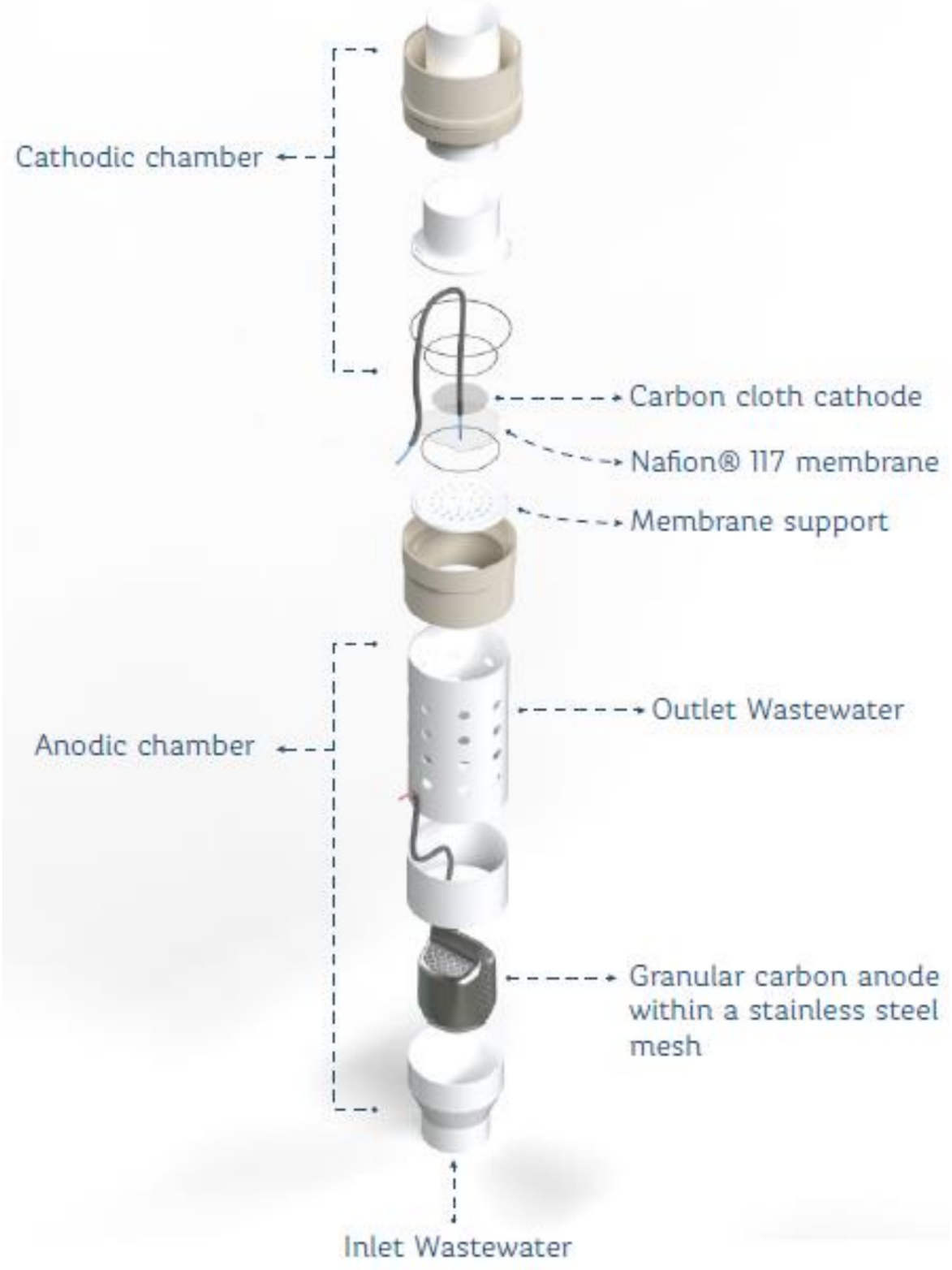

Figure 2. Microbial fuel cell (MFC) components and assembly for the 18 cells used in the MFCSS.

\subsection{Energy-Harvesting System (EHS)}

The EHS was built with $6.3 \mathrm{~V} \mathrm{UCC}{ }^{\circledR} 4700 \mu \mathrm{F}$ capacitors that harvest and store energy from the MFCs connected in parallel. Then, with a digital signal, NX3L2467 ${ }^{\circledR}$ analog switches change their configuration connecting all capacitors of the circuit cells of the stack in series with each other transferring power to auxiliary batteries (Ni-Mh Varta ${ }^{\circledR} 2.4 \mathrm{~V}$ ) connected in parallel. The energy management algorithm was programmed on a microcontroller Atmega $328 \mathrm{~PB}^{\circledR}$. In addition, a remote data logger was implemented to measure the stack voltage and current with an Arduino MKR GSM $1400^{\circledR}$. The EHS was designed and built with ultra-low energy consumption requirements to work on inactive and active mode; the total energy consumption in all step-up amplifying steps was $10.37 \mathrm{~J} \mathrm{day}^{-1}$. Connecting each MFC- $1 \ldots \mathrm{n}$ to a capacitor $\mathrm{C} 1 \ldots \mathrm{C}$ that stores the charge was proposed. When the control system detects the desired voltage level is reached, analog switches SW1 ... n start to transfer power; they disconnect the capacitors of the cells and afterwards they connect capacitors in series resulting in the sum of the voltages of the stack [20]. 


\subsection{Analytical Techniques}

To evaluate changes in water quality along the different steps of the MFCSS, measurements were made according to wastewater Mexican law, as follows: fecal coliforms, temperature, fat and oil, sedimentable solids, total suspended solids (TSS), biochemical oxygen demand (BOD), total nitrogen (TN), total phosphorus (TP), $\mathrm{pH}$, floating matter and COD. These parameters were determined with the procedures described in Mexican Official Standard NOM-001-SEMARNAT-1996 that establishes the maximum permissible limits of pollutants in wastewater discharges into national waters and soil [18].

In order to assess the power transfer efficiency related to equivalent series resistance (ESR), storage devices were tested with potenciostatic electrochemical impedance spectroscopy (PEIS) with a galvanostat potentiostat Biologic VSP ${ }^{\circledR}$ booster; amplitude testing signal interval was 5 to $40 \mathrm{mV}$ and frequency interval was $500 \mathrm{kHz}$ to $10 \mathrm{MHz}$. Likewise, the voltage and current of all the MFCs were measured with a multimeter Fluke 289. These values were taken in open circuit voltage when the circuit was disconnected from the system.

\section{Results}

\subsection{AQUOX ${ }^{\circledR}-M F C S S$}

The MFCSS worked during 60 days with a real domestic wastewater influent coming from a residential unit with a flow rate of $600 \pm 100 \mathrm{~L} \mathrm{~d}^{-1}$. The results for water quality parameters taken from the samples collected during day 60 of operation are shown in Table 1 for 4 different steps during the treatment process: (i) raw influent, (ii) septic tank effluent, (iii) AQUOX ${ }^{\circledR}$ effluent, and (iv) AQUOX ${ }^{\circledR}$ effluent + sodium hypochlorite. Tests were performed according to Mexican Official Standard NOM-001-SEMARNAT-1996 by a certified laboratory [18].

The values for all of the parameters for the effluent of the MFCSS system after chlorination were lower than the maximum permissible limits for wastewater discharge established in the NOM-001-SEMARNAT-1996-C as daily average (D.A.) and monthly average (M.A.). The hydraulic retention time (HRT) for the MFCSS was $3.3 \mathrm{~d}$. The organic load was $0.20 \pm 0.5 \mathrm{~kg} \mathrm{~m}^{-3} \mathrm{~d}^{-1}$. The HRT of the septic tank greater than 2 days is within the range of $2-5$ days recommended value for a septic tank to perform well [21]. The removal efficiency of contaminants for the MFCSS without and with chlorination are shown in Table 2.

It can be seen that chlorination increases the removal efficiency of only selected contaminants: fecal coliforms and total nitrogen. This is why the process is considered a polishing step to comply with regulation.

\subsection{EHS Behavior}

The current values of each MFC were $2 \mathrm{~mA}$ and $1.8 \mathrm{~mA}$ on average for the cells in stack 1 and stack 2, respectively (Figure 3a,b). For the battery voltage, the behavior was observed in Figure $3 \mathrm{c}$ (it keeps the battery charge). Each fuel cell was 15 days at open circuit voltage before installing the EHS (circuit connection) to the MFCSS. 
Table 1. Results of the wastewater quality after each step in the treatment process. D.A.—daily average; M.A.—monthly average.

\begin{tabular}{|c|c|c|c|c|c|c|}
\hline Parameters & Raw Influent & Septic Tank Effluent & AQUOX Effluent & $\begin{array}{c}\text { AQUOX Effluent }+ \\
\text { Calcium Hypochlorite }\end{array}$ & $\begin{array}{l}\text { NOM } 001 \\
\text { (D.A) }\end{array}$ & $\begin{array}{l}\text { NOM } 001 \\
\text { (M.A) }\end{array}$ \\
\hline Fecal Coliforms (MPN $100 \mathrm{~mL}^{-1}$ ) & $4,782,786 \pm 6,748,324$ & $1,216,606 \pm 2,017,474$ & $1,055,249 \pm 1,711,376$ & $3 \pm 0$ & 2000 & 1000 \\
\hline Temperature $\left({ }^{\circ} \mathrm{C}\right)$ & $29 \pm 1$ & $31 \pm 0.1$ & $30.7 \pm 0.2$ & $30.7 \pm 1.1$ & 40 & 40 \\
\hline Fat and Oil $\left(\mathrm{mg} \mathrm{L}^{-1}\right)$ & $59 \pm 2$ & $48 \pm 5$ & $6 \pm 1$ & $4 \pm 0$ & 25 & 15 \\
\hline Sedimentable Solids $\left(\mathrm{mL} \mathrm{L}^{-1}\right)$ & $4 \pm 2$ & $3 \pm 2$ & $0.3 \pm 0.01$ & $0.3 \pm 0.01$ & 2 & 1 \\
\hline Total Suspended Solids $\left(\mathrm{mg} \mathrm{L}^{-1}\right)$ & $224 \pm 21$ & $217 \pm 12$ & $10 \pm 0.1$ & $10 \pm 0.1$ & 60 & 40 \\
\hline Biochemical Oxygen Demand $\left(\mathrm{mg} \mathrm{L}^{-1}\right)$ & $242 \pm 48$ & $75 \pm 16$ & $34 \pm 10$ & $12 \pm 2$ & 60 & 30 \\
\hline Total Nitrogen $\left(\mathrm{mg} \mathrm{L}^{-1}\right)$ & $63 \pm 10$ & $61 \pm 8$ & $44 \pm 9$ & $9.6 \pm 0.5$ & 25 & 15 \\
\hline Total Phosphorus ( $\mathrm{mg} \mathrm{L}^{-1}$ ) & $11 \pm 3$ & $7 \pm 1$ & $4 \pm 0.2$ & $4 \pm 0.2$ & 10 & 5 \\
\hline $\mathrm{pH}$ & $8.2 \pm 0.2$ & $7.4 \pm 0.2$ & $7.4 \pm 0.2$ & $6.9 \pm 0.5$ & $5-10$ & $5-10$ \\
\hline Floating Matter & Present & Present & Absent & Absent & \multicolumn{2}{|c|}{ Absent } \\
\hline Chemical Oxygen Demand $\left(\mathrm{mg} \mathrm{L}^{-1}\right)$ & $789 \pm 42$ & $316 \pm 36$ & $114 \pm 12$ & $100 \pm 10$ & - & - \\
\hline
\end{tabular}

Table 2. Removal efficiency of contaminants by the MFCSS using hypochlorite as a final polishing step.

\begin{tabular}{|c|c|c|}
\hline Parameters & \% Removal Efficiency (without Hypochlorite) & \% Removal Efficiency (with Hypochlorite) \\
\hline Fecal Coliforms (MPN·100 $\mathrm{mL}^{-1}$ ) & 0 & 100 \\
\hline Fat and Oil $\left(\mathrm{mg} \mathrm{L}^{-1}\right)$ & 90 & 93 \\
\hline Sedimentable Solids $\left(\mathrm{mL} \mathrm{L}^{-1}\right)$ & 90 & 90 \\
\hline Total Suspended Solids $\left(\mathrm{mg} \mathrm{L}^{-1}\right)$ & 95 & 95 \\
\hline Biochemical Oxygen Demand $\left(\mathrm{mg} \mathrm{L}^{-1}\right)$ & 87 & 95 \\
\hline Total Nitrogen $\left(\mathrm{mg} \mathrm{L}^{-1}\right)$ & 30 & 84 \\
\hline Total Phosphorus (mg L $\left.{ }^{-1}\right)$ & 64 & 64 \\
\hline Chemical Oxygen Demand $\left(\mathrm{mg} \mathrm{L}^{-1}\right)$ & 86 & 87 \\
\hline
\end{tabular}



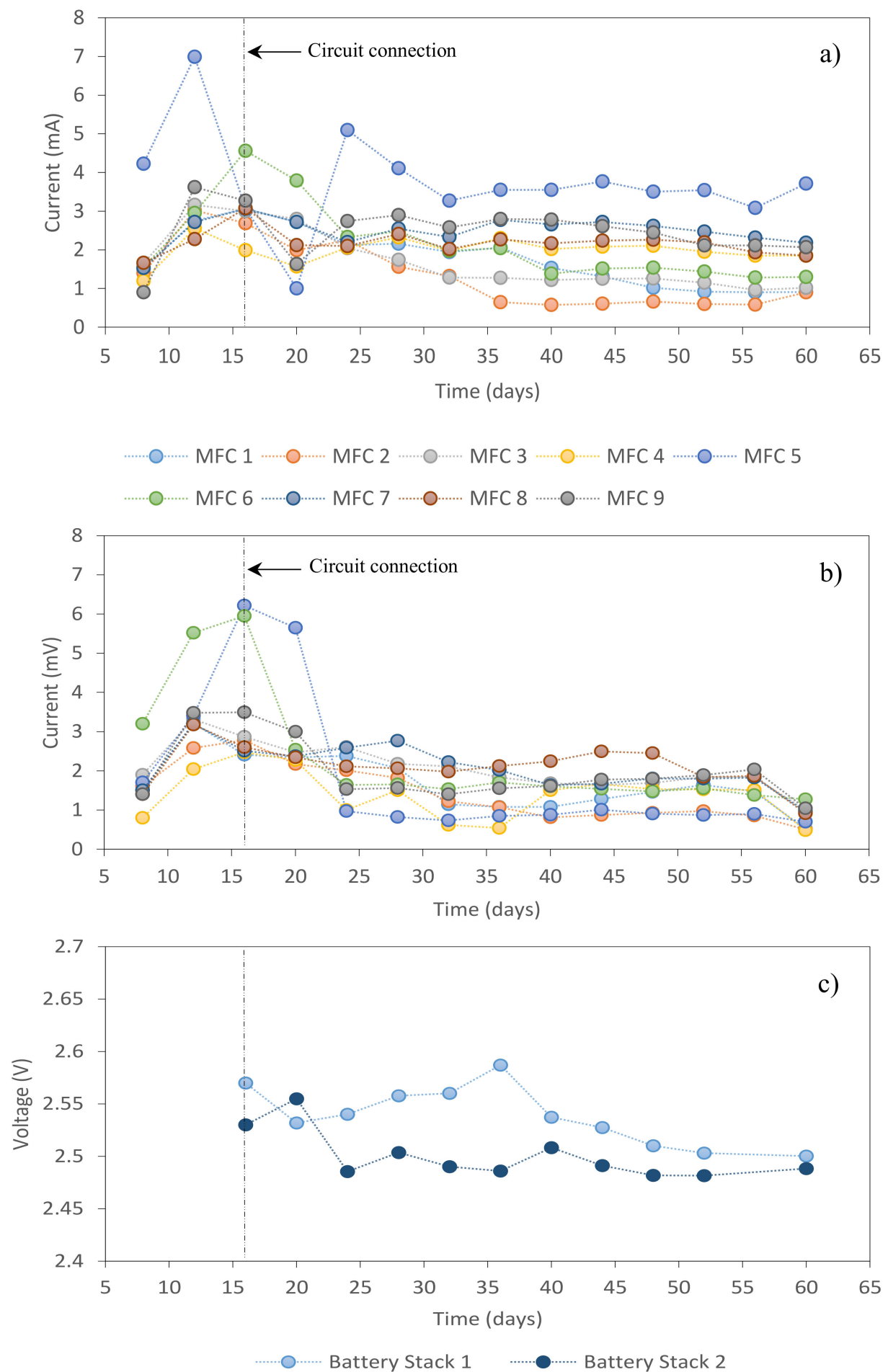

Figure 3. Current values of the cells in (a) Stack 1 and (b) Stack 2 over the 60-day period of the experiment (c) Voltage values of the energy-harvesting circuit battery circuit for Stack 1 and Stack 2 over time.

The values of power decreased over the harvesting time (connected in parallel with each other-voltage reversal phenomenon) as observed in Figure 4a. The coulombic efficiency calculated was $22 \pm 1.5 \%$ (data not shown). Likewise, the harvesting time was $1 \mathrm{~s}$ in the circuit. 

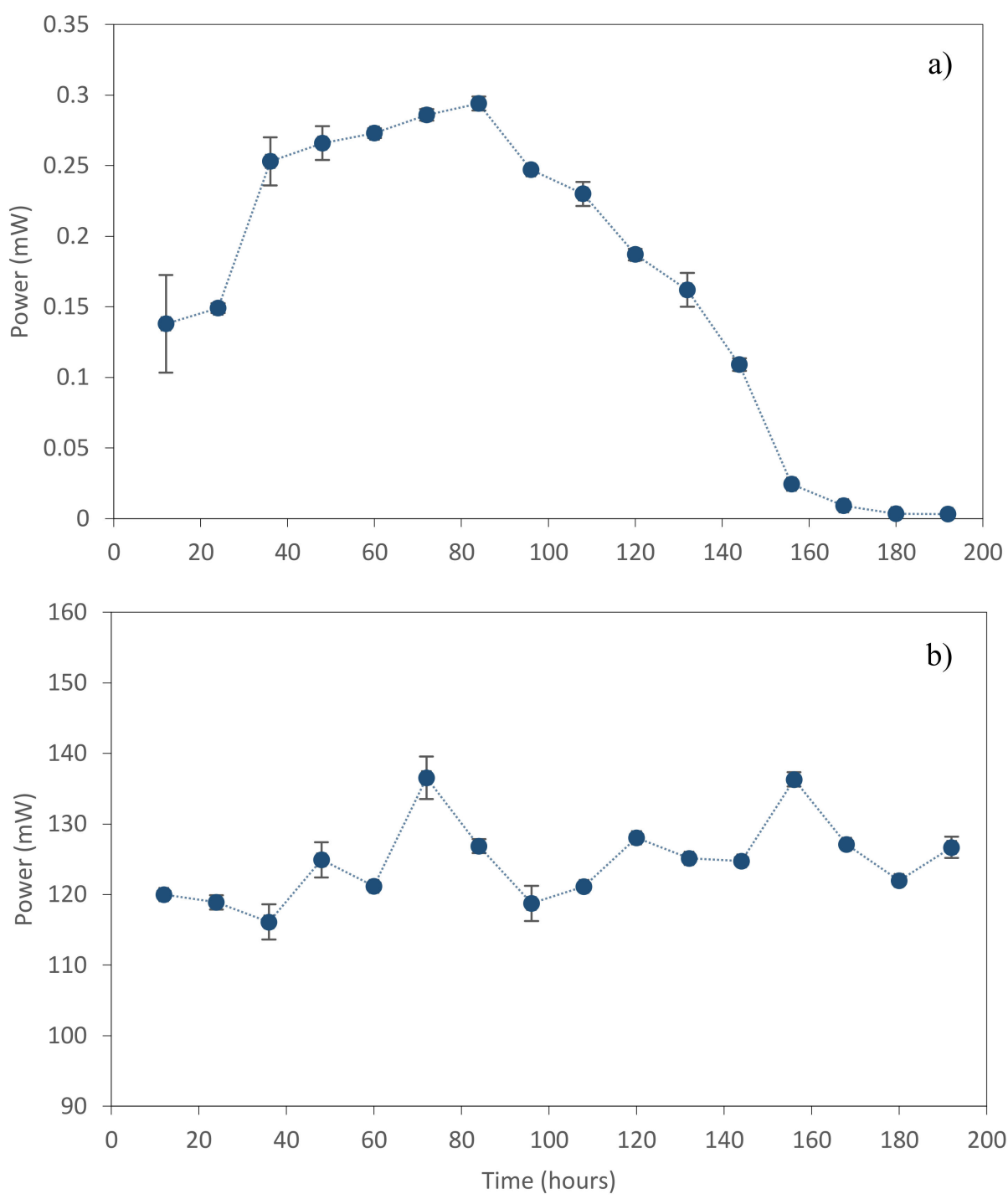

Figure 4. Power over time obtained from (a) stacked MFCs connected in parallel with each other (voltage reversal phenomenon), (b) energy-harvesting circuit.

\section{Discussion}

\subsection{Scaling Up a Microbial Fuel Cell (MFC) System}

In literature there are several efforts to scale up MFCs; Table 3 shows a summary of the most significant attempts. There is a tendency to use carbonaceous material for the scale-up prototypes, because these materials are cheaper, with a big surface area that maintains a large ratio of electrode surface against reactor volume and is compatible with the exoelectrogens bacterial growth in the anode making a good cost-effective option especially with GAC (used in this study as well) $[15,16]$. Likewise, it can be concluded that MFCs with packed electrodes (GAC) generally show higher COD removal rates and achieve higher power density [22].

COD removal achieved in several studies ranges from 36 to $84 \%$, whereas in the present study the COD removal with MFCSS was $87 \pm 4.5 \%$, using similar materials for the anode electrode. A previous work [11], achieved a good COD removal (70-80\%) with a working volume of $1000 \mathrm{~L}$, which is the largest volume tested for treating real wastewater, although they used a cascade system consisting of 3 stacks of 3 cells each (with 1 stack only a 33\% COD removal was obtained). Besides, an artificial catholyte was used, which had to be aerated constantly, making it not practical for real life implementation. 
Table 3. Summary of design for scale-up systems using microbial fuel cells

\begin{tabular}{|c|c|c|c|c|c|c|c|c|c|c|c|c|}
\hline Design & $\begin{array}{l}\text { Number } \\
\text { of Cells }\end{array}$ & $\begin{array}{l}\text { Working } \\
\text { Volume } \\
\text { (L) }\end{array}$ & $\begin{array}{l}\text { Initial } \\
\text { COD } \\
(\mathrm{mg} / \mathrm{L})\end{array}$ & HRT (d) & $\begin{array}{c}\text { COD } \\
\text { Removal } \\
(\%)\end{array}$ & $\begin{array}{l}\text { Waste } \\
\text { Type }\end{array}$ & Anode Material & $\begin{array}{l}\text { Cathode } \\
\text { Material }\end{array}$ & $\begin{array}{l}\text { MFC } \\
\text { Type }\end{array}$ & Separator & $\begin{array}{c}\text { Energy } \\
\text { Consumption }\end{array}$ & Reference \\
\hline Planar & 150 & 1000 & 250 & 2 & $70-80$ & $\begin{array}{l}\text { Municipal } \\
\text { wastewater }\end{array}$ & $\begin{array}{c}\text { Granular } \\
\text { activated carbon }\end{array}$ & $\begin{array}{c}\text { Granular } \\
\text { activated } \\
\text { carbon }\end{array}$ & $\begin{array}{l}\text { Double } \\
\text { chamber }\end{array}$ & CEM & $\begin{array}{l}\text { Catholyte air } \\
\text { pump and } \\
\text { recirculation }\end{array}$ & [11] \\
\hline Tubular & 96 & 192 & 103 & 12 & 76 & $\begin{array}{l}\text { Municipal } \\
\text { wastewater }\end{array}$ & Carbon brush & $\begin{array}{l}\text { Carbon cloth } \\
\text { with nitrogen } \\
\text { coated carbon }\end{array}$ & $\begin{array}{c}\text { Air } \\
\text { cathode }\end{array}$ & $\begin{array}{c}\text { CEM } \\
\text { CMI-7000 }\end{array}$ & $\begin{array}{l}\text { Catholyte } \\
\text { pump }\end{array}$ & [13] \\
\hline Planar & 6 & 65 & 1900 & 9.6 & 36 & $\begin{array}{l}\text { Swine } \\
\text { manure }\end{array}$ & $\begin{array}{l}\text { Granular } \\
\text { graphite }\end{array}$ & Stainless steel & $\begin{array}{l}\text { Double } \\
\text { chamber }\end{array}$ & $\begin{array}{c}\text { AEM } \\
\text { AMI-7001 }\end{array}$ & $\begin{array}{l}\text { Catholyte } \\
\text { pump }\end{array}$ & [12] \\
\hline Tubular & 48 & 96 & 156 & 6 & 80 & $\begin{array}{l}\text { Municipal } \\
\text { wastewater }\end{array}$ & Carbon brush & $\begin{array}{l}\text { Carbon cloth } \\
\text { with nitrogen } \\
\text { coated carbon }\end{array}$ & $\begin{array}{c}\text { Air } \\
\text { cathode }\end{array}$ & $\begin{array}{c}\text { CEM } \\
\text { CMI-7000 }\end{array}$ & $\begin{array}{l}\text { Catholyte } \\
\text { pump }\end{array}$ & [14] \\
\hline Rectangular & 10 & 90 & 124 & 6 & 84 & $\begin{array}{c}\text { Brewery } \\
\text { wastewater }\end{array}$ & Carbon brush & $\begin{array}{l}\text { Activated } \\
\text { carbon with } \\
\text { PTFE }\end{array}$ & $\begin{array}{c}\text { Air } \\
\text { cathode }\end{array}$ & $\begin{array}{l}\text { Textile } \\
\text { separator }\end{array}$ & $\begin{array}{l}\text { Wastewater } \\
\text { pump }\end{array}$ & [10] \\
\hline Tubular & 18 & 700 & 789 & 3.3 & $87 \pm 4.5$ & $\begin{array}{l}\text { Domestic } \\
\text { wastewater }\end{array}$ & $\begin{array}{c}\text { Granular carbon } \\
\text { + stainless steel } \\
\text { mesh }\end{array}$ & $\begin{array}{l}\text { Carbon cloth } \\
\text { with Vulcan } \\
\text { carbon }\end{array}$ & $\begin{array}{c}\text { Air } \\
\text { cathode }\end{array}$ & $\begin{array}{l}\text { CEM } \\
\text { Nafion } \\
117\end{array}$ & $\begin{array}{l}\text { Gravity-driven, } \\
\text { no energy } \\
\text { consumption }\end{array}$ & This study \\
\hline
\end{tabular}


The advantage of the scale up in this work compared to the others is that no electrical energy was required for the system to function, which translates into savings in operating and energy costs for real-life implementation. Another study achieved a COD removal of $36 \%$ (lower than $87 \pm 4.5 \%$ achieved in this study), attributed to complex and high concentration $\left(2.5 \mathrm{~g} \mathrm{~L}^{-1}\right.$ of COD) of the swine manure wastewater used, in fact, high concentration wastewaters have proved to decrease the COD removal up to $12 \%$ [12]. Likewise, another test achieved a COD removal between $60-70 \%$ lower than this study using a similar cell stack and municipal wastewater as substrate [11].

The scale up design should implement other techniques in biocathodes, artificial catholyte and catalysts to achieve a good COD removal performance in real wastewater treatment systems. The incorporation of MFC technology to anaerobic digestion processes has been suggested as a low-cost alternative due to the ease of coupling both processes based on the content of volatile fatty acids (VFAs) as acetates that can be easily degraded by MFCs [23-25]. Likewise, the anaerobic digestion process is compatible with high concentration wastewater and MFCs are ideal for medium- and low-strength wastewater (with less than $1 \mathrm{~g}$ COD per liter), meaning that MFCs are a good option for polishing or post-treatment of anaerobic digestion processed water as was shown in this work [24,26].

\subsection{Treatment Performance in $A Q U O X^{\circledR}$-MFCSS}

The MFCSS could effectively remove organic and nitrogen compounds via a three-step process (septic tank for primary treatment $+\mathrm{AQUOX}^{\circledR}+$ sodium hypochlorite). Total nitrogen (TN) is a nutrient present in wastewater coming from protein waste in the human body through urine. As observed in Table 2, the low removal efficiency of $30 \%$ was due to migration and diffusional process of $\mathrm{NH}_{3}{ }^{+}$ (principal component in domestic wastewater for nitrogen) through the CEM (Cation exchange membrane) in each MFC by passive aeration within the air cathode, finally reaching an $84 \%$ removal efficiency using hypochlorite.

The disinfection process is important in wastewater due to health risks involving pathogenic microorganisms. There is a variety of commercial products that can disinfect such as free chlorine, combined chlorine, chlorine dioxide, ozone and ultraviolet (UV) lamps. For this work a free chlorine product (sodium hypochlorite) was used due to safety and security reasons for the final user and also due to its low cost.

In the disinfection process, hypochlorite reacts with ammonia present in the wastewater to form chloramine species, which have greater disinfecting effect, reaching the break-point where chloramine species are oxidized to nitrogen gas and hydrochloric acid, decreasing residual chlorine. For this reason, with the chlorination process fecal coliforms and TN are reduced [27]. Previous literature has reported that wastewater chlorination process can produce disinfection by-products (DBPs) and many of these have been identified with genotoxic, mutagenic and or carcinogenic activities [28], but high ammonia concentrations ( $>15 \mathrm{mg} \mathrm{L}^{-1}$ ) have been found to suppress the formation of these compounds $[29,30]$. In this work the $\mathrm{N}-\mathrm{NH}_{3}$ values in wastewater were around $60 \mathrm{mg} \mathrm{L}^{-1}$, indicating that $\mathrm{N}^{-\mathrm{NH}_{3}}$ is the major component of TN, which is favorable for the chlorination process. Common trends for TN removal in literature include biocathodes constructed for the recirculation of anolyte and catholyte aeration for denitrification and nitrification processes [28]; for this reason, previous experiments [31-33] have reported greater removal efficiencies (66-90\%) compared to the present work, but all of them are controlled experiments in which the $\mathrm{NH}_{3}{ }^{+}$ion concentration is bigger than other ions present in the medium, which is unrealistic in domestic raw wastewater. It has been reported that ion exchange membranes suffer ion competence depending of ionic concentration in the medium [34,35]; in Yucatán, Mexico, the water contains a huge concentration of other ions (i.e., calcium) with hardness values of $450 \mathrm{mg} \mathrm{L}^{-1}$ as $\mathrm{CaCO}_{3}$, reason why $\mathrm{NH}_{3}{ }^{+}$ion transport through the membrane is not higher, resulting in a low TN removal for the system before chlorination.

For the fecal coliforms parameter used as possible association with enteric pathogens [33], the final value with hypochlorite was $3 \mathrm{MPN} 100 \mathrm{~mL}^{-1}$, which is low compared to the established limit in NOM-001-SEMARNAT-1996 (1000 MPN $100 \mathrm{~mL}^{-1}$ ) [18]. 
The TSS removal in AQUOX ${ }^{\circledR}$-MFCSS was $95 \%$. Previous literature has reported that MFCs are capable of removing TSS. For example, Jiang et al. [36] obtained a pilot-scale MFC system that removed $70 \%$ of TSS; the authors attributed this result to a particle retention process in pores among GAC, as implemented in the anode of the AQUOX ${ }^{\circledR}$-MFCSS [36]. Tian et al. [37] obtained a TSS removal of $57 \%$ attributed to substrate degradation in MFCs, suggesting that this value is low and to achieve a greater removal, improving the hydrolysis of substrate was necessary [37]. Likewise, a MFC that treated real wastewater without having any pretreatment achieved 50\% removal of TSS in [38].

The AQUOX ${ }^{\circledR}$-MFCSS removed $86 \%$ and $87 \%$ of total COD and BOD, respectively, at a HRT of $43 \mathrm{~h}$. The organic concentration in the raw influent was $242 \pm 48 \mathrm{mg} \mathrm{L}^{-1}$ as BOD. Whereas, the BOD effluent after treatment was $34 \pm 10 \mathrm{mg} \mathrm{L}^{-1}$. Additionally, the MFCSS did remove TP in $64 \%$, due mainly to the biomass uptake during the 43-h residence time, resulting in a final concentration of $4.0 \pm 0.2 \mathrm{mg} \mathrm{L}^{-1}$, similar to the removal rates reported by other authors [13,14].

\subsection{EHS Performance}

Although in literature there is a variety of EHSs, it is fundamental to choose one that suits the particular need of the system [39]. It is important to remember that the power source of the EHS are living organisms; for this reason the energy quantity that can be harvested and the frequency with which it must be done has to be taken into consideration. The EHS used in this work was a capacitor-based system operated in an intermittent energy harvest (IEH) mode because it has been reported that it is possible to harvest twice as much energy compared to the continuous energy harvest (CEH) mode [7,40-43] and prevent voltage reversal in the cells.

One of the main challenges in EHSs is the autonomy of the circuit. The circuit used in this work is capable of self-powering maintaining the charge of a $2.4 \mathrm{~V} \mathrm{Ni}-\mathrm{Mh}$ battery. This is possible due to the harvesting of the energy to the 9 MFCs in the stack, combined with the ultra-low consumption in the circuit (10.37 J or $125 \mu \mathrm{W})$ [44-46].

The total energy harvested of the 9 cells was variable depending of the capacitor charge time (CCT) used ( 1 or $3 \mathrm{~s})$. When a CCT of 3 was used the energy harvested was $9.33 \mathrm{~J}$, which is slightly lower than the consumption in the EHS circuit. This is why a decrease in voltage level of the main battery was observed. When the CCT was changed to $1 \mathrm{~s}$ the energy harvested was $15.55 \mathrm{~J}, 50 \%$ higher than the energy consumption in the circuit, allowing to maintain the charge level in the battery for self-powering the circuit. A capacitor-based EHS was used in the ECOBOT III harvesting $2 \mathrm{~J}$ of 48 MFCs with a microcontroller operating in a low mode, maintaining the energy level to power the ECOBOT functions [47].

The voltage reversal effect was evaluated with 9 stacked MFCs installed in a MFCSS under real domestic wastewater conditions and connected in parallel to each other with a resistive load of $497 \Omega$ to confirm voltage reversal effect reported in other stacked cells [48]. The maximum voltage measured with the load was $0.382 \mathrm{~V}$ with a current of $0.77 \mathrm{~mA}$ and a power of $0.294 \mathrm{~mW}$. Figure $4 \mathrm{a}$ shows that after $84 \mathrm{~h}$ the stack reaches maximum power and then begins to fall to zero as the voltage reversal occurs between cells resulting in lower current $(0.09 \mathrm{~mA})$. Organic matter starvation and an inadequate distribution of concentration in the substrate causes one or several cells of the stack to present concentration losses and this is the major cause of cell voltage reversal [49]. Usually two modes to collect electrons from MFCs are implemented: the first one is by IEH, reporting 3 times more electrical charge scavenging than the second mode, $\mathrm{CEH}$. This difference is due to the capacitor used in IEH which acts like a variable resistor; at the beginning of the capacitor charging step, its initial transient resistance is nearly zero, increasing linearly with the increase of MFC voltage up to infinite resistance at open circuit potential [50]. The maximum power transferred was $136.55 \mathrm{~mW}$ with an average voltage harvested in the 9 MFCs of $0.456 \mathrm{~V}$ and an amplified voltage by the serial-connected capacitors of $4.78 \mathrm{~V}$ (Figure $4 \mathrm{~b}$ ). The harvested energy data from stacked MFCs were acquired with the same GSM remote data transmission system [51]. 


\subsection{Economic Analysis}

A total of 3300 USD were invested in preparing the MFCSS to treat $600 \pm 100 \mathrm{~L} \mathrm{~d}^{-1}$, consisting of 2 modules and its energy-harvesting circuits respectively. The investment for a stacked MFC module (9 MFCs + energy-harvesting circuit), based on current prices from vendors was 285 USD. However, the costs of the components for different MFCs reactors reported in literature are quite different. For example in this study $38 \%$ of the cost was consumed by the use of cationic membranes, whereas for Liang et al. [11] $80 \%$ of the investment went to the PVC-based chambers, titanium mesh-based current collector, and the expensive CEM used. Another system comprising 200 L MFCs with 96 tubular modules used over $60 \%$ of the cost (6000 USD) for the CEM [11,13]. The cost of the MFC reactor operated in this study can still be further reduced if the materials are purchased at wholesale (cationic membrane, stainless steel mesh, among others). It is important to note that the materials used in this study have been scaled from the lab.

From Table 4, for a MFCSS of 18 cells (2 stacks), the total cost with the EHS for each stack is 285 USD. Additionally, to complete the wastewater treatment system used in this study, the cost of adding a primary treatment polyethylene tank sums 900 USD (ROTOPLAS, CdMex-Mexico), and the disinfection unit sums 330 USD (INNOWATER, CdMex-Mexico). The total cost for a complete system is 1800 USD.

Table 4. Material cost for a MFC stack (9 cells) + energy-harvesting circuit.

\begin{tabular}{lcl}
\hline \multicolumn{1}{c}{ Materials } & Unit Cost (USD) & \multicolumn{1}{c}{ Company } \\
\hline Cation Exchange Membrane (N 117) & & $\begin{array}{l}\text { Gus Industry Co., Ltd. \& Mianyang } \\
\text { Prochema Commercial Co., Ltd. } \\
\text { (Hongkong, China) }\end{array}$ \\
$\begin{array}{l}\text { Carbon Cloth (GDL Carbon Cloth Untreated) } \\
\text { Carbon Black Vulcan (XC 72R) }\end{array}$ & 1.59 & $\begin{array}{l}\text { ElectroChem Inc. (Woburn, MA, USA) } \\
\text { Fuel Cell Store (College Station, TX, USA) }\end{array}$ \\
Granular Activated Carbon & 0.0033 & Carbotecnia (Jalisco, Mexico) \\
NAFION ${ }^{\circledR}$ 117 Solution 5\% Alcohol & 1.44 & Sono Tek Corporation (Milton, NY, USA) \\
Stainless Steel Mesh & 1.80 & Hebei Da Shang Wire Mesh Products Co., \\
Isopropyl Alcohol & 2.02 & Ltd. (Hebei, China) \\
PVC Tube (4 inches) & 0.01 & Bmedina (Merida, Mexico) \\
Others (PVC cement, cotton tow, pvc & 1.69 & Niplito (Merida, Mexico) \\
coupling) & 6.71 & Niplito (Merida, Mexico) \\
Sub Total & 25 & Deb space (Merida, Mexico) \\
Energy Harvesting Circuit & 63 & \\
Total Cost (9 MFCS) & 285 & \\
\hline
\end{tabular}

\section{Conclusions}

A MFC-based wastewater treatment pilot plant was operated during 60 days in practical conditions fed with a raw influent from a 3-bedroom house with the objective of assessing its performance in contaminant removal. The wastewater flow was of $600 \pm 100 \mathrm{~L} \mathrm{~d}^{-1}$. Results show that organic matter removal measured through COD, BOD and TSS were of $86 \%, 87 \%$ and $95 \%$, respectively. Nutrient removal was $84 \%$ for TN and $64 \%$ for TP. Fecal coliform removal was $100 \%$ due to the hypochlorite disinfection system. The parameters measured in the effluent of the system comply with the values required for the discharge by the NOM-001-SEMARNAT-1996-C, which establishes the maximum permissible limits of contaminants for wastewater discharges in soil and water.

The AQUOX ${ }^{\circledR}$-MFCSS consisted of 18 MFCs coupled to an energy-harvesting circuit, which collected the electrons in the system during organic matter oxidation. The system had a HRT of $43 \mathrm{~h}$ and an organic load of $0.2 \pm 0.5 \mathrm{Kg} \mathrm{m}^{-3} \mathrm{~d}^{-1}$. The main highlight of this research is the continuous operation of an MFC scaled-up system without the use of external energy. This research is expected to contribute in large-scale MFC systems to advance technology towards sustainable and energy-efficient wastewater treatment. 


\section{Patents}

There is a patent resulting from this work MX337952B.

Supplementary Materials: The following are available online at https:/ / cicy.repositorioinstitucional.mx/jspui/ handle/1003/812.

Author Contributions: Conceptualization, R.V.L. and L.A.-G.; methodology, J.D.-M., E.R.-L., G.P., A.C.-H., A.M., D.D.R., R.M.-C., G.C.-c. and C.G.B.; validation, J.D.-M., E.R.-L., G.P., A.C.-H., A.M., D.D.R., R.M.-C., G.C.-c. and C.G.B.; investigation, L.A.-G., J.D.-M., R.M.-C., G.C.-C.; writing-original draft preparation, R.V.L. and L.A.-G.; supervision, R.V.L., E.R.-L. and L.A.-G.; project administration, R.V.L., E.R.-L. and L.A.-G.; funding acquisition, R.V.L. and L.A.-G.

Funding: The authors thank the National Council for Science and Technology (CONACYT Grant No. 394731).

Acknowledgments: The authors acknowledge as well the support of the Renewable Energy Laboratory at CICY for providing the facilities to perform the experiments, in a joint collaboration with Rotoplas led by the Innovation, Research and Development team.

Conflicts of Interest: The authors declare no conflict of interest.

\section{References}

1. Cortés, F.I.A.; Pérez, M.L.; Mogollón, H.M. Mexico's water challenges for the 21st century. In Water Resources in Mexico; Springer: New York, NY, USA, 2012; pp. 21-38.

2. Alzate-Gaviria, L.; García-Rodríguez, O.; Flota-Bañuelos, M.; Del Rio Jorge-Rivera, F.; Cámara-Chalé, G.; Domínguez-Maldonado, J. Stacked-MFC into a typical septic tank used in public housing. Biofuels 2016, 7, 79-86. [CrossRef]

3. Potter, M.C. Electrical effects accompanying the decomposition of organic compounds. Proc. R. Soc. Lond. B 1911, 84, 260-276. [CrossRef]

4. Cohen, B.J. The bacterial culture as an electrical half-cell. J. Bacteriol. 1931, 21, 18-19.

5. Karube, I.; Matsunaga, T.; Mitsuda, S.; Suzuki, S. Microbial electrode BOD sensors. Biotechnology and bioengineering. Biotechnol. Bioeng. 1977, 19, 1535-1547. [CrossRef] [PubMed]

6. Bennetto, P. Microbes come to power. New Sci. 1987, 114, 36-39.

7. Santoro, C.; Flores-Cadengo, C.; Soavi, F.; Kodali, M.; Merino-Jimenez, I.; Gajda, I.; Greenman, J.; Ieropoulos, I.; Atanassov, P. Ceramic Microbial Fuel Cells Stack: Power generation in standard and supercapacitive mode. Sci. Rep. 2018, 8, 3281. [CrossRef] [PubMed]

8. Walter, X.A.; Merino-Jiménez, I.; Greenman, J.; Ieropoulos, I. PEE POWER ${ }^{\circledR}$ urinal II-Urinal scale-up with microbial fuel cell scale-down for improved lighting. J. Power Sources 2018, 392, 150-158. [CrossRef]

9. Janicek, A.; Fan, Y.; Liu, H. Design of microbial fuel cells for practical application: A review and analysis of scale-up studies. Biofuels 2014, 5, 79-92. [CrossRef]

10. Dong, Y.; Qu, Y.; He, W.; Du, Y.; Liu, J.; Han, X.; Feng, Y. A 90-liter stackable baffled microbial fuel cell for brewery wastewater treatment based on energy self-sufficient mode. Bioresour. Technol. 2015, 195, 66-72. [CrossRef]

11. Liang, P.; Duan, R.; Jiang, Y.; Zhang, X.; Qiu, Y.; Huang, X. One-year operation of 1000-L modularized microbial fuel cell for municipal wastewater treatment. Water Res. 2018, 141, 1-8. [CrossRef]

12. Vilajeliu-Pons, A.; Puig, S.; Salcedo-Dávila, I.; Balaguer, M.; Colprim, J. Long-term assessment of six-stacked scaled-up MFCs treating swine manure with different electrode materials. Environ. Sci. Water Res. Technol. 2017, 3, 947-959. [CrossRef]

13. Ge, Z.; He, Z. Long-term performance of a 200 liter modularized microbial fuel cell system treating municipal wastewater: Treatment, energy, and cost. Environ. Sci. Water Res. Technol. 2016, 2, 274-281. [CrossRef]

14. Ge, Z.; Wu, L.; Zhang, F.; He, Z. Energy extraction from a large-scale microbial fuel cell system treating municipal wastewater. J. Power Sources 2015, 297, 260-264. [CrossRef]

15. Logan, B.E.; Wallack, M.J.; Kim, K.-Y.; He, W.; Feng, Y.; Saikaly, P.E. Assessment of microbial fuel cell configurations and power densities. Environ. Sci. Technol. Lett. 2015, 2, 206-214. [CrossRef]

16. Sonawane, J.M.; Yadav, A.; Ghosh, P.C.; Adeloju, S.B. Recent advances in the development and utilization of modern anode materials for high performance microbial fuel cells. Biosens. Bioelectron. 2017, 90, 558-576. [CrossRef] 
17. Logan, B.E. Exoelectrogenic bacteria that power microbial fuel cells. Nat. Rev. Microbiol. 2009, 7, 375-381. [CrossRef] [PubMed]

18. Semarnat. Norma Oficial Mexicana NOM-001-SEMARNAT-1996. Que establece los Límites Máximos Permisibles de Contaminantes en las Descargas de Aguas Residuales en Aguas y Bienes Nacionales; Diario Oficial de la Federación: Mexico City, Mexico, 1996.

19. Prakash, G.S.; Viva, F.A.; Bretschger, O.; Yang, B.; El-Naggar, M.; Nealson, K. Inoculation procedures and characterization of membrane electrode assemblies for microbial fuel cells. J. Power Sources 2010, 195, 111-117. [CrossRef]

20. Ford, T.D. Wearable Power Supply Comprising a Master Cell and a Slave Cell. U.S. Patents 9413181B2, 9 August 2016.

21. Méndez Novelo, R.; Gijón Yescas, A.; Quintal Franco, C.; Osorio Rodríguez, H. Determinación de la tasa de acumulación de lodos en fosas sépticas de la ciudad de Mérida, Yucatán. Ingeniería 2007, 11, 55-64.

22. Deeke, A.; Sleutels, T.H.; Donkers, T.F.; Hamelers, H.V.; Buisman, C.J.; Ter Heijne, A. Fluidized capacitive bioanode as a novel reactor concept for the microbial fuel cell. Environ. Sci. Technol. 2015, 49, 1929-1935. [CrossRef]

23. He, L.; Du, P.; Chen, Y.; Lu, H.; Cheng, X.; Chang, B.; Wang, Z. Advances in microbial fuel cells for wastewater treatment. Renew. Sustain. Energy Rev. 2017, 71, 388-403. [CrossRef]

24. Pham, T.; Rabaey, K.; Aelterman, P.; Clauwaert, P.; De Schamphelaire, L.; Boon, N.; Verstraete, W. Microbial fuel cells in relation to conventional anaerobic digestion technology. Eng. Life Sci. 2006, 6, 285-292. [CrossRef]

25. Sadhukhan, J.; Lloyd, J.R.; Scott, K.; Premier, G.C.; Eileen, H.Y.; Curtis, T.; Head, I.M. A critical review of integration analysis of microbial electrosynthesis (MES) systems with waste biorefineries for the production of biofuel and chemical from reuse of $\mathrm{CO}_{2}$. Renew. Sustain. Energy Rev. 2016, 56, 116-132. [CrossRef]

26. Oh, S.T.; Kim, J.R.; Premier, G.C.; Lee, T.H.; Kim, C.; Sloan, W.T. Sustainable wastewater treatment: How might microbial fuel cells contribute. Biotechnol. Adv. 2010, 28, 871-881. [CrossRef] [PubMed]

27. Howe, K.J.; Crittenden, J.C.; Hand, D.W.; Trussell, R.R.; Tchobanoglous, G. Principles of Water Treatment; John Wiley \& Sons: New York, NY, USA, 2012.

28. Richardson, S.D.; Plewa, M.J.; Wagner, E.D.; Schoeny, R.; DeMarini, D.M. Occurrence, genotoxicity, and carcinogenicity of regulated and emerging disinfection by-products in drinking water: A review and roadmap for research. Mutat. Res./Rev. Mutat. Res. 2007, 636, 178-242. [CrossRef]

29. Matamoros, V.; Mujeriego, R.; Bayona, J.M. Trihalomethane occurrence in chlorinated reclaimed water at full-scale wastewater treatment plants in NE Spain. Water Res. 2007, 41, 3337-3344. [CrossRef] [PubMed]

30. Sun, Y.-X.; Wu, Q.-Y.; Hu, H.-Y.; Tian, J. Effect of ammonia on the formation of THMs and HAAs in secondary effluent chlorination. Chemosphere 2009, 76, 631-637. [CrossRef] [PubMed]

31. Xie, S.; Liang, P.; Chen, Y.; Xia, X.; Huang, X. Simultaneous carbon and nitrogen removal using an oxic/anoxic-biocathode microbial fuel cells coupled system. Bioresour. Technol. 2011, 102, 348-354. [CrossRef]

32. Zhang, F.; He, Z. Integrated organic and nitrogen removal with electricity generation in a tubular dual-cathode microbial fuel cell. Process Biochem. 2012, 47, 2146-2151. [CrossRef]

33. Zhang, X.; Zhu, F.; Chen, L.; Zhao, Q.; Tao, G. Removal of ammonia nitrogen from wastewater using an aerobic cathode microbial fuel cell. Bioresour. Technol. 2013, 146, 161-168. [CrossRef]

34. Rozendal, R.; Sleutels, T.; Hamelers, H.; Buisman, C. Effect of the type of ion exchange membrane on performance, ion transport, and pH in biocatalyzed electrolysis of wastewater. Water Sci. Technol. 2008, 57, 1757-1762. [CrossRef]

35. Sleutels, T.H.; Hamelers, H.V.; Rozendal, R.A.; Buisman, C.J. Ion transport resistance in microbial electrolysis cells with anion and cation exchange membranes. Int. J. Hydrogen Energy 2009, 34, 3612-3620. [CrossRef]

36. Jiang, D.; Curtis, M.; Troop, E.; Scheible, K.; McGrath, J.; Hu, B.; Suib, S.; Raymond, D.; Li, B. A pilot-scale study on utilizing multi-anode/cathode microbial fuel cells (MAC MFCs) to enhance the power production in wastewater treatment. Int. J. Hydrogen Energy 2011, 36, 876-884. [CrossRef]

37. Tian, Y.; Mei, X.; Liang, Q.; Wu, D.; Ren, N.; Xing, D. Biological degradation of potato pulp waste and microbial community structure in microbial fuel cells. RSC Adv. 2017, 7, 8376-8380. [CrossRef]

38. Zhang, F.; Ge, Z.; Grimaud, J.; Hurst, J.; He, Z. Long-term performance of liter-scale microbial fuel cells treating primary effluent installed in a municipal wastewater treatment facility. Environ. Sci. Technol. 2013, 47, 4941-4948. [CrossRef] [PubMed] 
39. Wang, H.; Park, J.-D.; Ren, Z.J. Practical energy harvesting for microbial fuel cells: A review. Environ. Sci. Technol. 2015, 49, 3267-3277. [CrossRef] [PubMed]

40. Dewan, A.; Beyenal, H.; Lewandowski, Z. Intermittent energy harvesting improves the performance of microbial fuel cells. Environ. Sci. Technol. 2009, 43, 4600-4605. [CrossRef]

41. Do, M.; Ngo, H.; Guo, W.; Liu, Y.; Chang, S.; Nguyen, D.; Nghiem, L.; Ni, B. Challenges in the application of microbial fuel cells to wastewater treatment and energy production: A mini review. Sci. Total Environ. 2018, 639, 910-920. [CrossRef] [PubMed]

42. Hsu, L.; Mohamed, A.; Ha, P.T.; Bloom, J.; Ewing, T.; Arias-Thode, M.; Chadwick, B.; Beyenal, H. The influence of energy harvesting strategies on performance and microbial community for sediment microbial fuel cells. J. Electrochem. Soc. 2017, 164, H3109-H3114. [CrossRef]

43. Wang, Y.; Chen, Y.; Wen, Q. Microbial fuel cells: Enhancement with a polyaniline/carbon felt capacitive bioanode and reduction of Cr (VI) using the intermittent operation. Environ. Chem. Lett. 2018, 16, 319-326. [CrossRef]

44. Dallago, E.; Barnabei, A.L.; Liberale, A.; Malcovati, P.; Venchi, G. An interface circuit for low-voltage low-current energy harvesting systems. IEEE Trans. Power Electron. 2015, 30, 1411-1420. [CrossRef]

45. Lee, I.; Kim, G.; Bang, S.; Wolfe, A.; Bell, R.; Jeong, S.; Kim, Y.; Kagan, J.; Arias-Thode, M.; Chadwick, B. System-on-mud: Ultra-low power oceanic sensing platform powered by small-scale benthic microbial fuel cells. IEEE Trans. Circuits Syst. I Regul. Pap. 2015, 62, 1126-1135. [CrossRef]

46. Shaikh, F.K.; Zeadally, S. Energy harvesting in wireless sensor networks: A comprehensive review. Renew. Sustain. Energy Rev. 2016, 55, 1041-1054. [CrossRef]

47. Ieropoulos, I.A.; Greenman, J.; Melhuish, C.; Horsfield, I. Microbial fuel cells for robotics: Energy autonomy through artificial symbiosis. ChemSusChem 2012, 5, 1020-1026. [CrossRef] [PubMed]

48. Oh, S.-E.; Logan, B.E. Voltage reversal during microbial fuel cell stack operation. J. Power Sources 2007, 167, 11-17. [CrossRef]

49. Aelterman, P.; Rabaey, K.; Pham, H.T.; Boon, N.; Verstraete, W. Continuous electricity generation at high voltages and currents using stacked microbial fuel cells. Environ. Sci. Technol. 2006, 40, 3388-3394. [CrossRef] [PubMed]

50. Berchmans, S. Microbial Fuel Cell as Alternate Power Tool: Potential and Challenges. In Microbial Fuel Cell; Springer: New York, NY, USA, 2018; pp. 403-419.

51. Ma, Y.C.; Huang, Y.H. General application research on GSM module. Appl. Mech. Mater. 2012, 151, 96-100. [CrossRef] 